\title{
ТВОРЕННЯ НОВИХ ІМЕННИКІВ БАГАТООСНОВНИМИ СПОСОБАМИ (НА МАТЕРІАЛІ ГАЗЕТИ «УКРАЇНА МОЛОДА»)
}

Віняр Г. М. Творення нових іменників багатоосновними способами (на матеріалі газети «Україна молода»).

У статті розглянуто словотвірну структуру складних і складноскорочених іменників, що виникли в українській мові останнім часом. Матеріалом дослідження послужили публіцистичні та інформаційні тексти газети "Україна молода" за 2005-2006 роки. Способи творення нової лексики в засобах масової інформації певною мірою відбивають тенденції сучасного новотворення загалом.

Ключові слова: композити, юкстапозит, абревіатура, багатоосновні способи словотвору, новотвір.

Виняр А. Н. Образование новых имен существительных многоосновными способами (на материале газеты «Україна молода").

В статье рассматривается словообразовательная структура сложных и сложносокращенных имен существительных, возникших в украинском языке за последнее время. Материалом исследования послужили публицистические и информационные тексты газеты «Україна молода» за 2005-2006 годы. Способы образования новой лексики в средствах массовой информации в определенной степени отражают тенденции современного новообразования в целом.

Ключевые слова: композит, юкстапозит, аббревиатура, многоосновные способы словообразования, новообразование.

Vinyar A. N. Formation of new names of nouns by the multibasic ways (on a material of the newspaper " Ukraine is young ").

The article deals with the word formation structure of complex and complexabbreviated names of the nouns which have arisen in the Ukrainian language lately. As a material of research the publicistic and information texts of the newspaper " Ukraine is young " for 20052006 years. The ways of formation of new lexicon in mass media in the certain degree reflect the tendencies of modern newformation as a whole.

Key words: a composite, a ukstaposite, abbreviation, multibasic ways of wordformation, newformation.

Найбільшу групу новотворів серед іменників складають слова, що мають у своїй структурі дві і більше твірні основи. Такі деривати об’єднують кілька класів структурних одиниць, які різняться способом творення. До цієї групи способів словотворення належать основоскладання (композиція), словоскладання (юкстапозиція) та скорочення (абревіація). Поділ складних слів на композити і юкстапозити часто не визнається дослідниками, однак, як зазначає Н. Ф. Клименко, «при вивченні одного зрізу мови їх доцільно розрізняти для того, щоб виявити характерні тенденції словотвору певної мови, з'ясувати синтаксичну та семантичну основу формування різнотипних складних слів» $[1,4]$. Творення складних слів переживає останніми десятиліттями період бурхливого розвитку. Окремі моделі словоскладання розвинулися в українській мові під впливом структури запозичень складного типу. 
У газеті "Україна молода" найбільшою мірою представлені нові іменники, утворені способом словоскладання (юкстапозиція). Для юкстапозитів характерне складання двох і більше оформлених слів або форм слів без сполучних голосних. Юкстапозити - це переважно слова, що складаються 3 двох іменників, у яких одна частина - прикладка, що поєднується з пояснюваним елементом. Вказуючи на ознаку предмета, прикладка разом з тим дає йому другу назву. Іменник, означуваний прикладкою, виступає основною назвою, а прикладка - уточнюючою, деталізуючою. Характерною ознакою прикладки $є$ iї властивість становити з іменником цілісну єдність: рок-музикант, реп-зірка, бізнес-коло, фан-тусовка, інтернет-видання тощо. Напр.: Тому навіть про досить драматичне розлучення реп-зірки з дружиною журналісти дізналися не одразу, не кажучи вже про звичайних шанувальників виконавия (2005, №37, с. 12); У вересні 2002-го він разом з іншими активістами фан-тусовки запустив сайт уболівальників (2005, №62, с. 11). За допомогою словоскладання творяться нові слова шляхом поєднання в одне слово кількох слів без сполучного голосного. Такі новотвори можна поділити на дві групи: складні слова, у яких відмінюється кожна частина, $\mathrm{i}$ складні слова, у яких відмінюється тільки останній компонент.

До першої групи належать нові іменники із сурядним зв'язком між складниками (комедія-трилер, базар-свято-шоу) та неологізми, побудовані за моделлю «означуване-означуюче» (книга-аналіз, майстер-ландшафтник, прем'єр-регіонал, кілер-підривник). Напр.: Учора, в другий день роботи легендарного ярмарку в селі Нові Сорочиниі на Полтавщині, начіональний базарсвято-шоу відвідав Президент Віктор Ющенко (2006, №152, с.1); За рейтингом Світового Клубу Мільйонерів, Neтiroff закріпився у трійці горілчаних брендів-лідерів світу, обійшовши навіть “Абсолют” (2006, №160, с.8).

Більш продуктивними є іменники другого типу. Для них характерні атрибутивні відношення між складниками, причому слово-атрибут знаходиться у препозиції. Одним із компонентів таких новотворів виступають слова іншомовного походження, серед яких найпоширенішими є:

арт: арт-кав'ярня, арт-організатор;

інтернет: інтернет-торги, інтернет-агенція;

медіа: медіафорум;

поп: поп-королева, поп-діва;

піар: піар-менеджер, піар-козир;

бізнес: бізнес-проиес;

рок: рок-фест.

Семантика зазначених компонентів стосується таких суспільних сфер і явищ, як музика, економіка, преса та інформація. Напр.: Маркіян Іващишин біля своєї арт-кав'ярні "Дзига» у Львові, яка вже давно стала культовою (2006, №154, с.6); Про че В'ячеслав Брюховецький розповів на пресконференції, що відбулася вчора в приміщенні інтернет-газети «Оглядач» (№159, с.2); Медіа-профспілка готова оскаржити рішення мера в суді 
(2006, №151, с.4); Одну з найяскравіших зірок російського поп-небосхилу Авраама Руссо минулої суботи обстріляли з автомата Калашникова (2006, №153, с.3); Здійснювати програму передбачається иляхом розробки комунікаційної стратегї та ї̈ реалізації при використанні різних каналів комунікації, піар-технологій $і$ форм інформаційно-роз'яснювальної роботи (2006, №153, с.4); Люди підозрюють військовиків у свідомому нехлюйстві: у такий спосіб, мовляв, хтось «замітає бізнес-сліди»! (2006, № 153, c. 1).

Також до цієї групи належать слова на зразок демо-запис, каверверсія, веб-сторінка, сайд-проект, фешн-індустрія, регбі-клуб. Напр.: Розробники курсу планують також запуск навчальної програми з веб-дизайну (№160, c.6).

За значенням прикладки юкстапозити можна поділити на окремі групи, які абсолютизують, уточнюють якесь поняття, предмет чи явище: $i$ тернет-братія, бізнес-коло, секс-символ, реаліті-шоу. Напр.: У иілому напрошується такий висновок: лобістські зусилля вітчизняних бізнес-кіл можливо мали б позитивні наслідки, якби було витримано баланс інтересів виробників і споживачів автомобільної техніки (2005, №60, с. 8); Подейкують, щзо секс-символ спочатку розплакалась, а потім виставила правовірного за поріг (2005, №60, с. 12).

Способом юкстапозиції можуть поєднуватися запозичені компоненти: фешн-бізнес, фейс-контроль, продаки-студія, мілітарі-шоу, топ-менеджмент, топ-менеджер. Напр.: "Айна, про вас зараз активно заговорили у зв'язку з дизайном гардеробу для Прем'єр-міністра Юлї Тимошенко, але ж ви не перший день у фешн-бізнесі" (2005, №32, с. 10).

Способом юкстапозиції можуть поєднуватися як українські, так і іншомовні компоненти: лихо-машина, квітка-первоцвіт, людина-зима, маиина-ипигун, дівчина-вітер, жінка-гроза, бізнес-коло, Інтернет-кав'ярня, інтернет-лічильник, інтернет-видання, інтернет-оголошення, інтернетдотепник. Напр.: 10 січня інтернет-видання "Телекритика" опублікувало статтю професора Валерія Івановича (2005, №11, с. 13); Люди мають пройти фейс-контроль, надати свої особисті дані (2005, №11, с. 12).

У публікаціях газети "Україна молода" часто вживаються нові іменники, які виникли способом основоскладання (композити). Для композитів характерне поєднання кількох основ за допомогою інтерфіксів чи без них. Аналізований матеріал дає можливість стверджувати, що композити утворені переважно на базі вільних словосполучень шляхом основоскладання за допомогою інтерфіксів $о$, $е$, досить часто з суфіксацією: нашоукраӥнець

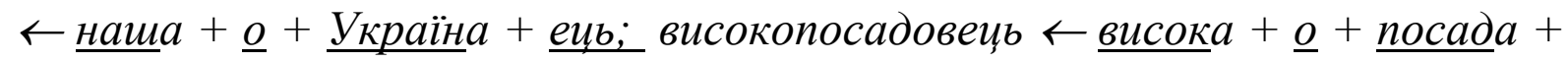

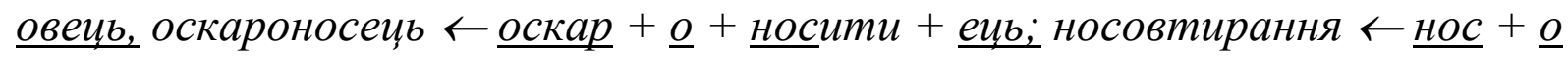
$+\underline{\text { втирати }}+\underline{\text { ння; }} \quad$ темникописець $\leftarrow \underline{\text { темник }}+\underline{o}+\underline{\text { писати }}+\underline{\text { ець } ;}$ єв-

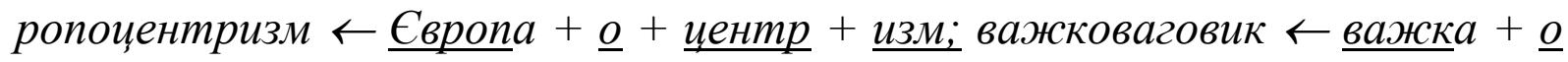

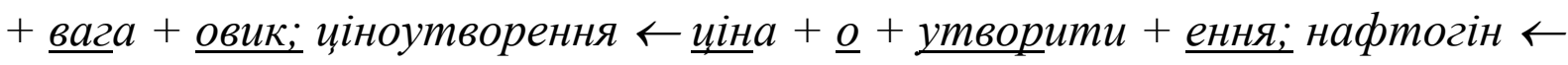




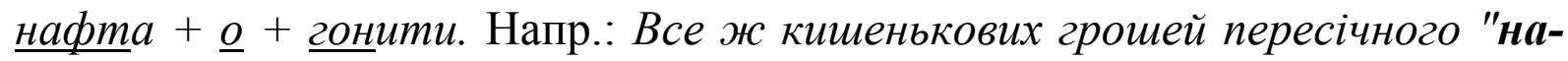
шоукраӥнця" виявилося не настільки багато, щуоб розмести "фірмові" дзиzарі (2005, №8, с. 11); Ввосьме в історї "красивого" списку "Піпл" на перших сходинках розмістилася темношкіра "оскароносиця" Холлі Перрі, пліч-о-пліч з якою протягом усіх изх років іде кралечка Джулія Робертс (2005, №32, с. 10).

Засвідчено в мові газети основоскладання за словотвірним зразком "залежний прикметник + іменник". До подібних утворень належать назви осіб, речей, предметів, абстрактних понять і процесів. Зазначені словотвірні категорії переважно утворюються чистим основоскладанням, рідше основоскладання з суфіксацією: електрохолдинг $\leftarrow$ електричний + холдинг;

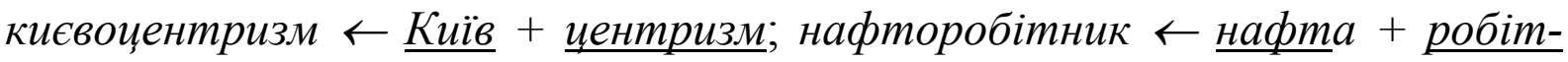
ник. Кількісно невелику групу складають композити, утворені на основі об'єктної конструкції "іменник + іменник". Вони утворюються чистим основоскладанням і є назвами предметів та понять: машиномісие, нафтотрейдер, м'ясопродукт тощо. Напр.: Також планується організувати додаткові паркінги для автомобілів на 1 тис. машиномісць, а паркування біля самого Палацу спорту буде заборонено (2005, №26, с. 3).

На межі між афіксацією й основоскладанням перебувають складні іменники, утворені за допомогою афіксоїдів, які ще називають лексикоморфемами, тому що, зберігаючи лексичну наповненість, вони у своїх функціях наближаються до дериваційних афіксів. У новотворенні беруть участь префіксоїди: авіа- (авіарейд), аудіо- (аудіорозповідь), біо- (біопальне), зоо- (зоокуток), кіно- (кіноінтонація), теле- (телеменю), радіо- (радіопротектор) та суфіксоїди: -знавець (кафкознавець), -ман (кіноман), філ (їжакофіл), -фобія (грузинофобія). Напр.: Відтак у кінодистриб'юторів було майже 9 місяиів, щзоб виносити і народити українські саундтреки чи субтитри (2006, №160, с.2); Напад на машину було здійснено тоді, коли журналісти знімали ізраӥльський авіарейд на Газу, підкреслює «Рейтер» (2006, №156, с.3); До слова, у світі багато країн виробляють біодизель із тієї сировини, на яку багаті (2006, №48, с.2).

Іменники, утворені за допомогою основоскладання, $\epsilon$ назвами осіб (зернотрейдер, прапороший), медичних (гіменопластика), політичних (коалічієтворення) або абстрактних понять (дитиночентризм). Напр.: Вареникоїди готуються до фіналу конкурсу, призначеного на 24 серпня (2006, №153, с.3); Звичайно, "дитиноцентризм», як зазначив президент Академії педагогічних наук Василь Кремінь, повинен бути в основі сучасної освіти (2006, №153, с.8); Згодом комісія лікарів, до складу якої входять педіатр та інфекиіоніст Теофіпольської центральної районної лікарні, вирішила провести імуноглобулінопрофілактику всім учням школи (2006, №219, с.2). Зрідка вживаються композити на позначення абстрактних понять та процесів переважно утворюються за словотвірними типами: з суфі-

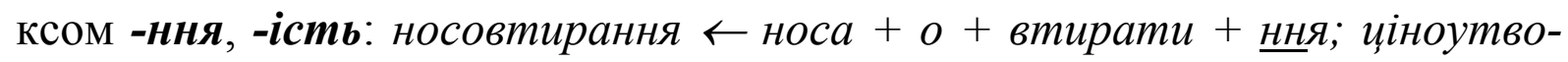




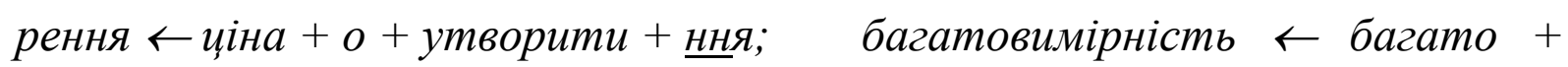
виміряти + ність. Напр.: "Фахівц̧і "Укрзалізниці" за рекомендацією Антимонопольного комітету Украӥни розроблять $і$ затвердять документи, щзо визначатимуть порядок ціноутворення на додаткові послуги" (2005, №24, c. 3); Продуктивно організувавши роботу кормережі, можна сміливо відійти від обридлих, хоча й уміло скопійованих шаблонів підприємського TV $i$ показати аудиторії Украӥну в усій ї̈ багатовимірності (2005, № 10 , с. 13).

Складні іменники в публікаціях газети "Україна молода" виступають не лише засобом номінації нових явищ дійсності, але й уживаються з метою посилення виразності: носовтирання, темникописецьь.

Значного поширення на сторінках газети "Україна молода" набула абревіація, яка виступає засобом концентрації в одному слові значення складеної назви. Її можна поділити на частковоскорочені абревіатури, скорочення ініціального типу, новотвори, які складаються з початкових частин слів, та багатокомпонентні ланцюжкові утворення. Частковоскорочена абревіація - це скорочення не всіх компонентів базового словосполучення, вони характеризуються наявністю повного слова. У сучасному новотворенні виявляють активність такі моделі оформлення частковоскорчених слів:

1. Абревіатури, утворені на базі узгодженого словосполучення "прикметник - іменник", у яких усічена частина прикметника приєднується до повного головного слова:

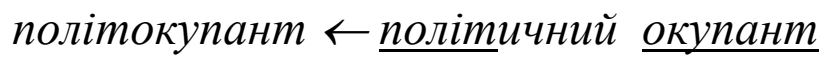

інформпростір $\leftarrow$ інформаційний простір

міжбанк $\leftarrow$ міжнародний банк

онкопроцес $\leftarrow$ онкологічний процес

адмінресурс $\leftarrow$ адміністративний ресурс

спецефект $\leftarrow$ спеціальний ефект

спеияконтингент $\leftarrow$ спецііальний контингент

спецприймальник $\leftarrow$ спеціальний приймальник.

Напр.: Інакше нічим не пояснити, з якої причини розговорився в "Независимой газете" чорний магістр усіх політичних магій, відомий ефектолог і полімокупант Гліб Павловський (2005, №237, с. 5).

2. Скорочення, які нагадують складні слова, оскільки усічення приєднується до повного слова за допомогою сполучного голосного:

євростандарт $\leftarrow$ європейський стандарт

єврокомісар $\leftarrow$ європейський комісар

єврокомісія $\leftarrow$ європейська комісія

євроклуб $\leftarrow$ європейський клуб

єврокубок $\leftarrow$ європейський кубок

євроліга $\leftarrow$ свропейська $+\underline{o}+\underline{\text { ліга }}$

євроробота $\leftarrow$ свропейська $+\underline{o}+$ робота

євростандарт $\leftarrow$ європейський $+\underline{o}+\underline{\text { стандарт }}$ 


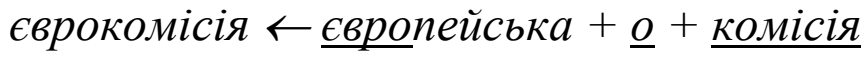

$$
\begin{aligned}
& \text { екосистема } \leftarrow \text { екологічна }+\underline{o}+\text { система. }
\end{aligned}
$$

3'явившись в останнє десятиліття, аброморфема євро- виявляє найбільшу активність в оформленні часткових скорочень. Напр.: Кращі українські командири провели в євролізі ФІФА перші матчі "плей-оф" (2005, №35, c. 14).

3. Абревіатури, у яких представлені найвагоміші з номінативної точки зору компоненти. Здебільшого це умовні назви, побудовані за моделлю часткових скорочень:

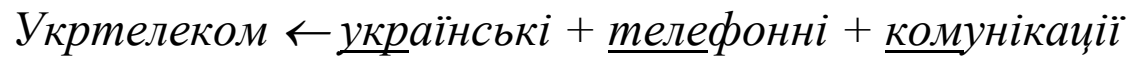

тервибочком $\leftarrow$ територіальний + виборий + комітет.

Напр.: Біля селища Демидівка Пирятинського району Полтавщини постраждали внаслідок вибуху двоє прачівників Укртелекомy (2005, №60, с. 2).

Ініціальний тип абревіації - це утворення складноскорочених слів від початкових звуків чи букв.

Звуковий тип складають слова, утворені поєднанням початкових зву-

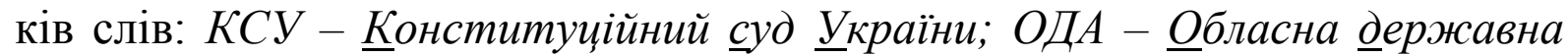
адміністрація. Напр.: Захист капіталовкладень трунтуватиметься на принципах і засадах СОT (ㅡвітова організація торгівлі) (2005, №159, с. 9). Особливість цього типу полягає в тому, що слова читаються як звичайні.

Буквений тип складають слова, утворені від назв початкових букв (слово вимовляється за назвами букв): ПДВ (nе-де-ве), ОБСС (o-бе-ес- $)$ ), ЦВК (це-ве-ка). Напр.: У лютому в Києві почне роботу місія іноземних спостерігачів бюро ОБСС (2005, №134, c. 5). Буквено-звуковий (змішаний)

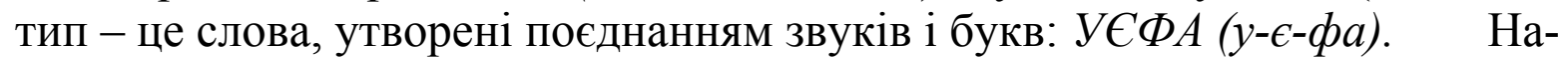
пр.: Мета "россонері" нині - саме четверте місие в "зоні Ліги чемпіонів" $i$ взяття Кубка УСФA (2005, №127, с. 8). Як свідчить матеріал газетних прублікацій, ініціальний тип є продуктивним у його перших двох різновидах (звуковий і буквений), змішаний використовується рідко.

Значна кількість складноскорочених слів стає основами для утворення нових слів за допомогою суфіксації (КРУ $\rightarrow$ "КРУшник", ДАI $\rightarrow$ даішник, СБУ $\rightarrow$ есбеушник, УНСО $\rightarrow$ унсовець, КОП $\rightarrow$ "копівеиь"). Напр.: Українським підприємствам навряд чи варто розраховувати на появу партнерів із середовища держав-"фатфівців" (від FATF) (2005, №169, с. 8).

Засвідчено ряд новотворів, які складаються з початкових частин слів (поскладові абревіатури): музфест $\leftarrow$ музичний фестиваль; страйкком $\leftarrow$ страйковий комітет; речдок $\leftarrow$ речовий доказ. Напр.: Цей бренд є офіиійним спонсором Roskilds Festival - найбільшого музфеста просто неба, де збираються більше 250000 прихильників гарного пива (2005, №168, с. 16); До речі, на суді виплив іще один "речдок" провини рескомівиів: посвідчення громадського інспектора згаданого комітету, виписане "фігурантами" власнику забудови паркінгу (2005, №22, с. 3). 
Багатокомпонентними ланцюжковими утвореннями є абревіатури, що містять не менше трьох компонентів. Абревіатурне оформлення багатокомпонентних новотворів відбувається за двома типами: 1) частковоскорочені багатоелементні абревіатури 3 кінцевим компонентом у вигляді повного слова:

держприкордонслужба $\leftarrow$ державна прикордонна служба держподатревізор $\leftarrow$ державний податковий ревізор держподатінспектор $\leftarrow$ державний податковий інспектор міськторгбізнес $\leftarrow$ міський торговельний бізнес райспорткомітет $\leftarrow$ районний спортивний комітет.

Напр.: Щоб провести валюту через митницю, росіянин заховав гроші у банку з варенням, повідомив прес-ијентр Держсприкордонслужкби України (2005, №60, с. 2).

Таким чином, нові абревіатури досить активно продукуються в українській мові новітнього періоду й використовуються в публікаціях газети "Україна молода".

Дослідження публіцистичних та інформаційних текстів газети «Україна молода» за 2005-2006 роки виявило 576 новотворів, що виникли внаслідок багатоосновного словотвору; кількісно найбільш представлені юкстапозити, активізація яких пов'язана з посиленням аналітичних рис в українському словотворенні, глобалізаційних впливів; успішно конкурує 3 іншими багатоосновними способами абревіація, передусім часткові скорочення.

\section{Література}

1. Клименко Н.Ф. Словотворча структура і семантика складних слів у сучасній українській мові / Ніна Федорівна Клименко. - К.: Наукова думка, 1984. - 257 с. 